\title{
PENGARUH EKUITAS MEREK DAN KEPERCAYAAN KONSUMEN \\ TERHADAP KEPUTUSAN PENGGUNAAN JASA EKSPEDISI (STUDI PADA KONSUMEN JALUR NUGRAHA EKAKURIR)
}

\author{
Erghana Kanza Kirana \\ Department of Management FEB UMM \\ E-mail : kanzakirana4@gmail.com
}

\begin{abstract}
This study aims to examine the impact of brand equity and consumer trust on decision to use the expedition service. The population of this study was the entire customers who sent their package in the JNE Malang; Meanwhile, the sample was 120 consumers who accidentally met while sending their package in the JNE office. The sample was selected by using accidental sampling technique. The data were analysed by means of Multiple Linear Regression. The findings indicated that (1) most of the consumers initially used JNE for the first time in 2014; (2) brand equity significantly influences decision to use the expedition service with the t-count value of 2.350 and the significance value of 0.020; (3) consumer trust also significantly influences decision to use the expedition service with the t-count value of 3.478 and the significance value of 0.001; and last, (4) from these two variables, consumer trust dominantly influences the decision to use the expedition service with a value of 0.301 .
\end{abstract}

Keywords: brand equity, consumer trust, decision to use the expedition service

\section{PENDAHULUAN}

Dalam memenuhi kebutuhan, setiap orang tentu mempunyai cara yang berbeda. Perbedaan caradari setiap orangdalam memenuhi kebutuhan bisa berubah tanpa perusahaan mampu untuk memprediksinya. Perilaku dalam memenuhi kebutuhan inilah yang menjadi dasar dalam menentukan keputusan penggunaan atas produk dan jasa.

Keputusan penggunaan ini sangat penting, dari keputusan penggunaan oleh konsumen, perusahaan dapat mengidentifikasi perbedaan perilaku konsumen dalam memutuskan untuk menggunakan produk dan jasa yang ditawarkan, produk dan jasa apa yang akan digunakan, mengapa konsumen menggunakan produk dan jasa tersebut, kapan konsumen akan menggunakannya.

Munculnya keputusan penggunaan suatu barang dan jasa oleh konsumen tentu dipengaruhi berbagai variabel. Wibowo, dkk (2013) mengungkapkan bahwa motivasi, kepercayaan, persepsi, sikap konsumen, kelompok, keluarga, pekerjaan, dan situasi ekonomi menjadi variabel yang mempengaruhi keputusan penggunaan. Selain itu, bauran pemasaran menjadi salah satu faktor 
yang dapat mempengaruhi keputusan penggunaan jasa ekspedisi. Putra, dkk (2014) menyatakan bahwa produk, harga, lokasi, promosi, bukti fisik, orang, dan proses menjadi bahan pertimbangan konsumen dalam memutuskan untuk menggunakan suatu jasa ekspedisi.

Dari beberapa faktor-faktor yang dapat mempengaruhi keputusan penggunaan, ekuitas merek merupakan salah satu faktor yang dapat mempengaruhi keputusan penggunaan. Ekuitas merek menggambarkan suatu bentuk aset yang terkandung dalam suatu merek yang ditawarkan perusahaan mencakup nama, logo, simbol untuk menjadi pertimbangkan bagi konsumen untuk menggunakan poduk dan jasa tersebut. Aaker (1991) mengungkapkan ada lima dimensi ekuitas merek, yaitu 1) kesadaran merek, 2) persepsi kualitas, 3) asosiasi merek, 4) loyalitas merek dan 5) Aset-aset lain yang dimiliki merek.

Selain ekuitas merek, kepercayaan konsumen memberikan andil yang bagi konsumen untuk memutuskan menggunakan jasa ekspedisi. Mowen dan Minor (2002) menjelaskan kepercayaan konsumen adalah semua bentuk pengetahuan yang dimiliki oleh konsumen dan semua kesimpulan yang dibuat oleh konsumen tentang objek, atribut dan manfaatnya. Kepercayaan konsumen menjadi salah satu pembanding dari apa yang diharapkan konsumen dengan apa yang telah diterima konsumen. Bilondatu (2013) mengung-kapkan bahwa kepercayaan merupakan keyakinan satu pihak mengenai maksud dan perilaku pihak yang lainnya, sehingga kepercayaan konsumen didefinisikan sebagai harapan konsumen bahwa penyedia barang dan jasa dapat dipercaya atau diandalkan dalam memenuhi janjinya. Konsumen cenderung memutuskan untuk menggunakan produk dan jasa berdasarkan apa yang mereka percayai tentang atribut-atribut yang terdapat di produk dan jasa tersebut.

Kepercayaan juga dapat dibangun melalui pengalaman masa lalu konsumen dalam menggunakan produk dan jasa. Pengalaman di masa lalu akan membentuk suatu kepuasaan maupun ketidakpuasan yang tentu akan memunculkan suatu kepercayaan terhadap produk dan jasa.

Fenomena yang terjadi saat ini adalah usaha dalam bidang jasa ekspedisi semakin berkembang dengan banyak berdirinya jasa ekspedisi untuk memenuhi kebutuhan konsumen dalam pengiriman barang. Beberapa jasa ekspedisi yang berdiri saling belomba-lomba dalam membangun ekuitas merek dan kepercayaan konsumen untuk memenangkan persaingan pasar jasa ekspedisi.

Berkembangnya tren bisnis online pada saat ini sedikit banyak mempengaruhi perkembangan jasa ekspedisi. Selain itu, banyaknya jasa ekspedisi yang berdiri memberikan pilihan alternatif bagi konsumen dalam memutuskan jasa ekspedisi yang akan digunakannya. Jasa ekspedisi tentu memberikan peran penting dalam pengiriman barang. Tanpa adanya jasa ekspedisi tentu barang-barang tidak dapat terdistribusikan secara merata.

Jalur Nugraha Ekakurir atau orang biasa menyebut sebagai JNE 
adalah salah satu perusahaan penyelenggara jasa ekspedisi di Indonesia. JNE telah memiliki 5000 titik layanan di seluruh Indonesia sampai dengan tingkat kecamatan sehingga sangat memudahkan konsumen untuk menjangkaunya.

Kemudahandalam menjangkau JNE ini diharapkan mampu untuk meningkatkan minat beli konsumen terhadap jasa ekpedisi JNE itu sendiri. Selain itu, JNE menyediakan gerai yang siap melayani pengiriman selama 24 jam di kota-kota besar agar memberikan pelayanan secara maksimal ketika konsumen melakukan transaksi kapanpun. JNE sebagai salah satu perusahaan jasa ekspedisi, tentu memberikan pelayanan terbaik bagi konsumennya. Pemberian pelayanan terbaik kepada konsumen ini adalah sebagai salah satu upaya JNE dalam membangun kepercayaan konsumen terhadapnya. Apabila konsumen percaya terhadap pelayanan JNE, konsumen tidak akan ragu untuk memutuskan untuk mengguakan JNE selanjutnya.

Berdasarakan uraian diatas, maka rumusan masalah penelitian ini adalah : (1) apakah ekuitas merek berpengaruh terhadap keputusan penggunaan jasa ekspedisi di JNE ?, (2) Apakah kepercayaan konsumen berpengaruh terhadap keputusan penggunaan jasa ekspedisi di JNE ? dan (3) variabel manakah yang memiliki kontribusi terbesar terhadap keputusan penggunaan jasa ekspedisi di JNE ?

Tujuan penelitian ini adalah sebagai berikut: (1) Untuk menguji pengaruh ekuitas merek terhadap keputusan penggunaan jasa ekspedisi di JNE, (2) Untuk penggunaan jasa ekspedisi di JNE, dan menguji pengaruh kepercayaan konsumen terhadap keputusan penggunaan jasa ekspedisi di JNE, dan (3) Untuk mengetahui variabel yang memiliki kontribusi terbesar terhadap keputusan penggunaan jasa ekspedisi di JNE.

\section{TINJAUAN PUSTAKA}

Peter dan Olson (2013) mengungkapkan keputusan penggunaan sebagai suatu proses integrasi yang digunakan untuk mengombinasikan pengetahuan dan mengevaluasi dua atau lebih alternatif dan memilih satu diantaranya.

Menurut Kotler dan Keller (2009) ekuitas merek adalah suatu nilai tambah yang diberikan kepada produk maupun jasa. Ekuitas merek tercermin dari cara berpikir, merasa, bertindak dalam berhubungan dengan suatu merek, pangsa pasar, harga, dan profitabilitas yang diberikan merek bagi perusahaan oleh seorang konsumen.

Kepercayan konsumen adalah semua pengetahuan yang dimiliki oleh konsumen dan semua kesimpulan yang dibuat konsumen tentang objek, atribut, dan manfaatnya (Mowen dan Minor, 2002).

Berdasarkan teori yang telah dijelaskan pada subbab sebelumnya, yang menunjukkan hubungan antara variabel ekuitas merek dan kepercayaan konsumen terhadap keputusan pengguanaan, maka dapat digambarkan kerangka pikir penelitian ini yang tersaji pada Gambar 1 berikut: 


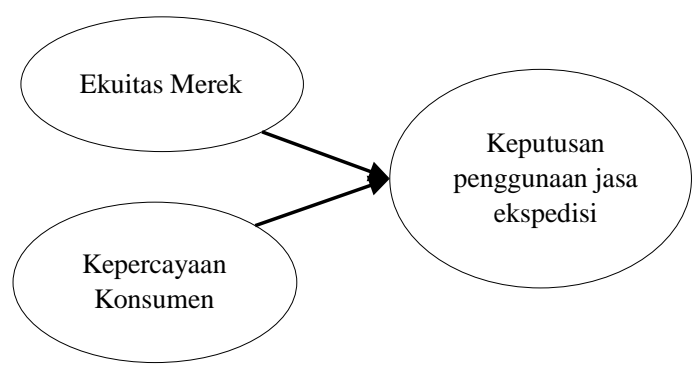

Gambar 1. Kerangka Pikir

Dewi, dkk (2013) dalam penelitiannya menunjukkan ekuitas merek berpengaruhdan signifikan terhadap keputusan dalam penggunaan jasa maskapai penerbangan Garuda Indonesia. Messie (2013) mengungkapkan bahwa dimensi-dimensi ekuitas merek berpengaruh langsung terhadap keputusan pembelian. Sehingga, Hipotesis 1 penelitian ini adalah ekuitas merek berpengaruh signifikan terhadap keputusan penggunaan jasa ekspedisi

Taroreh, dkk (2015) dalam penelitiannya menyimpulkan bahwa kepercayaan berpengaruh signifikan terhadap keputusan penggunaan pada jasa asuransi JASINDO. Selain itu, Ismayanti, dkk (2015) mengungkapkanbahwa kepercayaan konsumen berpengaruh secara parsial bernilai positif terhadap keputusan pembelian. Sehingga, Hipotesis 2 penelitian ini adalah kepercayaan konsumen berpengaruh signifikan terhadap keputusan penggunaan jasa ekspedisi

Jayanti (2015) dalam penelitiannya mengungkapkan bahwa kepercayaan konsumen berpengaruh dominan terhadap keputusan pembelian di Harapan Maulina Hijab Jombang secara Online. Meliana, dkk (2013) menyatakan bahwa kepercayaan konsumen menjadi variabel yang memiliki pengaruh dominan terhadap keputusan pembelian. Sehingga, Hipotesis 3 penelitian ini adalah kepercayaan konsumen berpengaruh dominan terhadap keputusan penggunaan jasa ekspedisi.

\section{METODE PENELITIAN}

Penelitian ini menggunakan analisis data kuantitatif dengan metode survei dengan mengambil objek Jalur Nugraha Ekakurir (JNE). Sumber data yang digunakan adalah data primer dan diperoleh dengan cara membagikan kuesioner kepada responden. Populasi pada penelitian ini ada semua konsumen yang mengirimkan paket di JNE Cabang Utama Malang, dengan sampel konsumen yang mengirimkan paket dan secara kebetulan bertemu di JNE Cabang Utama Malang. Jumlah yang sampel ditentukan sebanyak 120 responden. Teknik pengambilan sampel pada penelitian ini menggunakan teknik accidental sampling.

Definisi operasional variabel penelitian ini yaitu, Ekuitas merek $\left(\mathrm{X}_{1}\right)$ adalah segala aset yang terkandung dalam merek baik itu nama, simbol, dan dapat dijadikan pertimbangkan konsumen dalam membeli produk maupun jasa yang mencakup kesadaran merek, persepsi kualitas, asosiasi merek, dan loyalitas merek. Messie

(2013) 
mengungkapkan indikator ekuitas merek yaitu: (1) Logo JNE yang mudah dikenali, (2) JNE mempunyai layanan-layanan yang dikenali oleh konsumen (REG, YES, Diplomat Service, dan PESONA), (3) JNE mempunyai jaringan agen dan sub agen pengiriman yang luas, (4) JNE adalah merek jasa ekspedisi yang banyak dikenal, (5) Tarif di JNE terjangkau, (6) Menggunakan JNE tanpa terpengaruh oleh jasa ekspedisi merek lain, dan (7) Merekomendasikan JNE ke orang lain.

Kepercayaan Konsumen (X2) adalah persepsi yang terekam dalam benak konsumen bahwa mengirimkan paket melalui jasa ekspedisi JNE dapat dipercaya dan memenuhi persepsi yang ada. Menurut Wulandari (2014), indikator kepercayaan konsumen yaitu: (1) Paket sampai di alamat dengan keadaan utuh, (2) Paket tidak hilang dalam pengiriman, (3) Paket sampai di alamat tepat waktu, dan (4) Informasi yang diberikan JNE melalui website benar adanya.

Keputusan Penggunaan adalah suatu tindakan untuk mengirim suatu paket melalui jasa ekspedisi JNE oleh konsumen setelah mempertimbangkan alternatifalternatif pilihan yang dapat dipengaruhi oleh sikap orang lain dan situasi yang tidak diprediksi. Adapun indikator keputusan penggunaan menurut Massie (2013) adalah :(1) Menggunakan JNE dengan yakin, (2) Mencari informasi mengenai JNE, (3) Menggunakan layanan JNE setelah membandingkan dengan jasa ekspedisi lain, (4) Menggunakan jasa ekspedisi JNE merupakan pilihan yang tepat.

Pengumpulan data dalam penelitian ini menggunakan kuesioner yang dibagikan kepada konsumen yang mengirimkan paket dan secara kebetulan bertemu di JNE Cabang Utama Malang. Skala pada penelitian ini menggunakan skala Likert lima tingkat. Analisis data penelitian ini menggunakan regresi linear berganda dengan mengikuti kaidah asumsi klasik, dan koefisien determinas $\left(\mathrm{R}^{2}\right)$ dengan alat bantu SPSS.

\section{HASIL DAN PEMBAHASAN}

Pengelompokan responden yang menjadi sampel dijabarkan berdasarkan 2 kategori, yaitu, berdasarkan tahun menggunakan jasa ekspedisi JNE, dan berdasarkan waktu terakhir menggunakan jasa ekspedisi JNE. Berdasarkan hasil analisis, diketahui bahwa mayoritas responden mulai menggunakan jasa ekspedisi JNE pada tahun 2014 dan mayoritas responden menggunakan jasa ekspedisi JNE dalam rentang waktu 1 bulan yang lalu sebelum responden tersebut menggunakan jasa ekspedisi JNE kembali.

Uji validitas ini dilakukan dengan cara membandingkan $r_{\text {tabel }}$ dan $\mathrm{r}_{\text {hitung. Degree of Freedom (df) }}$ sebesar $\mathrm{n}-2$, sehingga nilai df yang dapat dihitung adalah 120-2 = 118, dan tingkat signifikansi sebesar 0,05, maka didapat nilai $r_{\text {tabel }}$ sebesar 0.179 . Hasil uji validitas dapa dilihat pada Tabel 1. 
Tabel 1. Hasil Uji Validitas

\begin{tabular}{|c|c|c|}
\hline Variabel & Item & $\begin{array}{l}\text { Corrected Item- } \\
\text { Total Correlation }\end{array}$ \\
\hline \multirow[t]{7}{*}{ Ekuitas Merek (X1) } & $\mathrm{X} 1.1$ & 0.627 \\
\hline & X1.2 & 0.607 \\
\hline & X1.3 & 0.672 \\
\hline & $\mathrm{X} 1.4$ & 0.621 \\
\hline & $\mathrm{X} 1.5$ & 0.581 \\
\hline & X.1.6 & 0.588 \\
\hline & X.1.7 & 0.513 \\
\hline Kepercayaan & $\mathrm{X} 2.1$ & 0.550 \\
\hline \multirow[t]{3}{*}{ Konsumen (X2) } & X.2.2 & 0.545 \\
\hline & X.2.3 & 0.517 \\
\hline & $\mathrm{X} 2.4$ & 0.511 \\
\hline Keputusan & Y.1 & 0.572 \\
\hline Penggunaan & Y.2 & 0.575 \\
\hline \multirow{2}{*}{ Ekspedisi (Y) } & Y.3 & 0.545 \\
\hline & Y.4 & 0.323 \\
\hline
\end{tabular}

Berdasarkan hasil uji validitas pada tabel 1, diketahui setiap item pernyataan kuesioner diperoleh nilai $\mathrm{r}$ hitung lebih besar daripada $\mathrm{r}$ tabel yang telah ditentukan, sehingga, dapat dikatakan bahwa setiap item dalam kuesioner valid.
Uji reliabilitas pada penelitian ini digunakan untuk mengukur konsistensi jawaban yang diberikan oleh responden pada setiap item pernyataan kuesioner. Hasil uji reliabilitas penelitian ini dapat dilihat pada Tabel 2 berikut ini:

Tabel 2. Hasil Uji Reliabilitas

\begin{tabular}{cccc}
\hline Variabel & $\begin{array}{c}\text { Koefisien } \\
\text { Cronbach } \\
\text { Alpha }\end{array}$ & $\begin{array}{c}\text { Batas } \\
\text { Standar }\end{array}$ & Keterangan \\
\hline $\begin{array}{c}\text { Ekuitas Merek (X1) } \\
\text { Kepercayaan Konsumen } \\
\text { (X2) }\end{array}$ & 0,743 & 0,60 & Reliabel \\
$\begin{array}{c}\text { Keputusan Penggunaan } \\
\text { Jasa Ekspedisi (Y) }\end{array}$ & 0,659 & 0,60 & Reliabel \\
\end{tabular}

Berdasarkan tabel 2 hasil uji relibilitas dapat dilihat masingmasing variabel memiliki nilai Croncbach Alpha lebih besar dari 0.6 sehingga instrument penelitian dapat dikatakan reliabel dan layak digunakan sebagai pengukur.
Analisis regresi linear berganda digunakan untuk mengetahui kekuatan hubungan atau pengaruh dari dua atau lebih variabel bebas terhadap variabel terikatnya. Hasil analisis regresi pada penelitian ini dapat dilihat pada Tabel 3.

Tabel 3. Hasil Analisis Regresi

\begin{tabular}{|c|c|c|c|c|c|}
\hline \multirow[t]{2}{*}{ Model } & \multicolumn{2}{|c|}{$\begin{array}{c}\text { Unstandardized } \\
\text { Coefficients }\end{array}$} & \multirow{2}{*}{$\begin{array}{c}\begin{array}{c}\text { Standardized } \\
\text { Coefficients }\end{array} \\
\text { Beta }\end{array}$} & \multirow[t]{2}{*}{$\mathrm{T}$} & \multirow[t]{2}{*}{ Sig. } \\
\hline & B & Std. Error & & & \\
\hline Konstanta & 12,586 & 1,164 & & 10,817 & 0,000 \\
\hline Ekuitas Merek $\left(\mathrm{X}_{1}\right)$ & 0,079 & 0,034 & 0,204 & 2,350 & 0,020 \\
\hline Kepercayaan Knsumen $\left(\mathrm{X}_{2}\right)$ & 0,188 & 0,054 & 0,301 & 3,478 & 0,001 \\
\hline
\end{tabular}


Berdasarkan hasil tabel 3, dapat diketahui bahwa nilai konstanta sebesar 12.586, nilai koefisien regresi variabel ekuitas merek 0.79 dengan nilai signifikansi sebesar 0.020 , nilai koefisien regresi variabel kepercayaan konsumen sebesar 0.188 dan nilai signifikansi diperoleh sebesar 0.001 .

Uji normalitas pada penelitian ini dilakukan untuk mengetahui apakah model regresi terbebas dari gejala normalitas, serta untuk mengetahui apakah data terdistribusi normal. Uji normalitas pada penelitian ini menggunakan uji Kolmogorov-Smirnov. Hasil uji normalitas penelitian dapat dilihat pada tabel 4.

Tabel 4. Hasil Uji Normalitas

\begin{tabular}{ccc}
\hline $\begin{array}{c}\text { Nilai Hasil } \\
\text { Uji } \\
\begin{array}{c}\text { Kolmogorov- } \\
\text { Smirnov }\end{array}\end{array}$ & $\begin{array}{c}\text { Batas } \\
\text { Signifikan } \\
\text { si }\end{array}$ & Keterangan \\
\hline 0.200 & 0.05 & Normal \\
\hline
\end{tabular}

Berdasarkan tabel 4, terlihat bahwa nilai signifikansi sebesar 0.200 yang dapat diartikan nilai signifikansi tersebut lebih besar dari 0.05 sehingga data terdistribusi secara normal.

Uji multikolonieritas bertujuan untuk menguji ada tidaknya korelasi antara variabel ekuitas merek, kepercayaan konsumen dalam model regresi. Hasil uji multikolonieritias dapat dilihat pada tabel 5 .

Tabel 5. Hasil uji multikolonieritas

\begin{tabular}{lcc}
\multicolumn{1}{c}{ Variabel } & \multicolumn{2}{c}{ Collinearity } \\
& Toleratistics \\
& Ekuitas Merek & VIF \\
(X1) & 0,996 & 1,004 \\
Kepercayaan & & \\
Konsumen (X2) & 0,996 & 1,004 \\
\hline
\end{tabular}

Berdasarkan hasil uji multikolonieritas pada tabel 5, terlihat bahwa nilai tolerance pada variabel bebas penelitian tidak ada yang kurang dari 0.10 dan nilai VIF variabel bebas penelitian tidak ada yang lebih dari 10. Sehingga dapat dikatakan bahwa regresi terbebas dari gejala multikolonieritas.

Uji heteroskedastitas dilakukan untuk menguji apakah terjadi ketidaksamaan variance dari residual pengamatan ke pengamatan yang lain. Uji heteroskedastisitas penelitian ini menggunakan uji glejser. Hasil uji heteroskedastisitas penelitian ini dipaparkan pada Tabel 6.

\begin{tabular}{ll}
\multicolumn{2}{c}{ Tabel 6. Hasil Uji } \\
Heteroskedastisitas \\
\hline \multicolumn{1}{c}{ Variabel } & Sig \\
\hline $\begin{array}{l}\text { Ekuitas Merek }\left(\mathrm{X}_{1}\right) \\
\text { Kepercayaan Konsumen }\end{array}$ & .422 \\
$\left(\mathrm{X}_{2}\right)$ & .328 \\
\hline
\end{tabular}

Hasil uji heteroskedastisitas pada tabel 6 , menunjukkan bahwa model regresi tidak terdapat gejala heteroskedastitas, karena nilai signifikansi masing-masing variabel bebas lebih besar dari 0.05 .

Uji autokorelasi dilakukan untuk menguji apakah dalam model regresi linear ada korelasi antara kesalahan penggangu dari suatu periode dengan periode sebelumnya. Uji autokorelasi penelitian ini menggunakan model Durbin Watson (DW). Berdasarkan hasil pengujian dengan bantuan SPSS, diperoleh nilai durbin watson sebesar 1.765. Nilai tersebut terletak diantara nilai dU dan nilai 4-dU. Sehingga, dapat dikatakan bahwa model regresi terbebas dari gejala autokorelasi. 
Tabel 7. Hasil Koefisien Determinasi $\left(\mathrm{R}^{2}\right)$

\begin{tabular}{cccc}
\hline $\mathrm{R}$ & $\mathrm{R}$ Square & $\begin{array}{c}\text { Adjusted } R \\
\text { Square }\end{array}$ & Std. Error of the Estimate \\
\hline $.353^{\mathrm{a}}$ & .125 & .110 & 1.294 \\
\hline
\end{tabular}

Berdasarkan Tabel 7, dapat diketahui nilai koefisien determinasi sebesar 0.125 atau sebesar $12.5 \%$, sehingga variabel ekuitas merek dan kepercayaan konsumen berpengaruh terhadap keputusan penggunaan jasa ekspedisi sebesar $12.5 \%$. Sisanya dapat dipengaruhi variabel lain yang tidak terdapat pada penelitian, seperti kualitas layanan, lokasi, harga, citra merek, dan word of mouth.

Uji parsial pada penelitian ini dilakukan untuk menguji variabel ekuitas merek dan kepercayaan konsumen terhadap keputusan penggunaan jasa ekspedisi secara parsial. Hasil uji T dapat dilihat pada Tabel 8:

Tabel 8. Hasil Uji T

\begin{tabular}{lcccc}
\hline \multirow{2}{*}{ Variabel } & \multicolumn{2}{c}{ Nilai } & \multirow{2}{*}{ Signifikansi } & \multirow{2}{*}{ Keterangan } \\
\hline Ekuitas Merek (X1) & 2.350 & 1.980 & 0.020 & Signifikan \\
Kepercayaan & 3.478 & 1.980 & 0.001 & Signifikan \\
Konsumen (X2) & & & \\
\hline
\end{tabular}

Berdasarkan Tabel 8, dapat diketahui bahwa nilai $t$ hitung variable ekuitas merek sebesar 2.350 dan nilai signifikansi diperoleh sebesar 0.020. Nilai t hitung variabel kepercayaan konsumen diperoleh sebesar 3.478 dengan nilai signifikansi 0.001 . Nilai $t$ hitung masing-masing variabel lebih besar dari t tabel yang telah ditentukan sebesar 1.980, dan nilai signifikansi masing-masing variable lebih kecil dari 0.05 , sehingga dapat dikatakan bahwa ekuitas merek dan kepercayaan konsumen berpengaruh signifikan terhadap keputusan penggunaan jasa ekspedisi.

Uji Kontribusi Terbesar (dominan) dilakukan untuk mengetahui pengaruh variabel bebas yang memiliki pengaruh lebih dominan terhadap variabel terikat. Hasil uji kontribusi terbesar ini dapat diketahui dengan membandingkan nilai Standardized Coefficients Beta masing- masing variabel bebas.Hasil uji dominan penelitian ini dapat dilihat pada Tabel 9:

Tabel 9. Hasil Uji Kontribusi Terbesar

\begin{tabular}{cc}
\hline Variabel & $\begin{array}{c}\text { Nilai Standarized } \\
\text { Coeficient Beta }\end{array}$ \\
\hline Ekuitas Merek (X1) & 0.204
\end{tabular}

Berdasarkan Tabel 9, dapat diketahui bahwa variabel kepercayaan konsumen memiliki nilai Standarized Coeficient Beta lebih besar daripada variabel ekuitas merek, sehingga dapat disimpulkan bahwa kepercayaan konsumen memiliki pengaruhi dominan terhadap keputusan penggunaan jasa ekspedisi

Hasil penelitian yang ditunjukkan melalui hasil regresi linear berganda menunjukkan bahwa variabel ekuitas merek berpengaruh 
signifikan terhadap keputusan penggunaan jasa ekspedisi. Hasil uji regresi tersebut mempunyai nilai positif yang dapat diartikan bahwa semakin baik ekuitas merek yang dimiliki oleh JNE, semakin meningkat pula keputusan penggunaan jasa ekspedisi JNE oleh konsumen.

Hasil penelitian yang ditunjukkan melalui hasil regresi linear berganda menunjukkan bahwa variabel kepercayaan konsumen berpengaruh signifikan terhadap keputusan penggunaan jasa ekspedisi. Hasil uji regresi tersebut mempunyai nilai positif yang dapat diartikan bahwa semakin tinggi kepercayaan konsumen terhadap JNE, semakin tinggi pula keputusan penggunaan jasa ekspedisi JNE oleh konsumen.

Hal tersebut terjadi karena kepercayaan konsumen terhadap jasa ekspedisi JNE terbentuk karena terpenuhinya harapan dan kebutuhan untuk mengirimkan paket oleh konsumen tersebut.Kepercayaan juga akan timbul apabila konsumen telah merasakan kepuasan karena telah menggunakan produk jasa ekspedisi JNE. Konsumen yang merasa puas dan percaya tentu akan memutuskan untuk menggunakannya secara yakin, tepat, dan tanpa pertimbangan yang banyak.

Kepercayaan konsumen berpengaruh dominan terhadap keputusan penggunaan jasa ekspedisi. Berdasarkan hasil analisis uji kontribusi terbesar, dapat diketahui bahwa kepercayaan konsumen berpengaruh dominan terhadap keputusan penggunaan. Hasil analisis juga menunjukan bahwa dengan semakin besar kepercayaan yang dimiliki konsumen, dapat memberikan dampak atau pengaruh yang paling besar terhadapkeputusan penggunaan jasa ekspedisi di JNE.

Hal tersebut terjadi karena Kepercayaan konsumen merupakan salah satu hal terpenting bagi perusahaan yang bergerak dalam bidang jasa. Apabila kepercayaan yang dimiliki konsumen rendah terhadap perusahaan tersebut, maka akan dengan cepat dan mudah bagi konsumen beralih ke perusahaan pesaing. Selain itu, dengan mempertahankan kepercayaan konsumen, perusahaan akan tetap menjaga hubungan jangka panjang dengan para konsumennya

\section{KESIMPULAN}

Berdasarkan hasil penelitian yang telah dijelaskan sebelumnya, dapat diketahui bahwa variable ekuitas merek berpengaruh signifikan terhadap keputusan penggunaan jasa ekspedisi. Begitu juga pada variabel kepercayaan konsumen berpengaruh signifikan terhadap keputusan penggunaan jasa ekspedisi.

Selain itu, dari hasil penelitian menunjukkan bahwa kepercayaan konsumen memiliki pengaruh yang dominan terhadap keputusan penggunaan jasa ekspedisi disbanding dengan variabel ekuitas merek.

\section{DAFTAR PUSTAKA}

Aaker, David A.1991.Managing Brand Image: Capitalizing on the Value of a Brand Name. New York: The Free Press Bilondatu, Machrani Rinandha.2013.Motivasi, 
Persepsi, dan Kepercayaan Pengaruhnya Terhadap Keputusan Pembelian Konsumen Pada Sepeda Motor Yamaha di Minahasa.Jurnal EMBA.Vol.1 No.3. Hal. 710-720

Dewi, Shandra Kusuma, Apriatni E.P dan Sari Listyorini.2013. Pengaruh Ekuitas Merek dan Promosi Terhadap Keputusan Penggunaan Jasa Maskapai Penerbangan Garuda Indonesia. Diponegoro Journal of Social and Politic. pp 1-8

Ismayanti ,Ni Wayan Nonik,I Wayan Suardana, dan I Made Kusuma Negara. 2015. Pengaruh Kepercayaan dan E-Service Quality Terhadap Keputusan Pembelian Akomodasi di Bali Pada Situs Booking.com. Jurnal IPTA Vol. 3 No. 1, Hal 56-61

Jayanti, Ratna Dwi. 2015. Pengaruh Haga dan Kepercayaan Terhadap Keputusan Pembelian Secara Online (Studi Kasus Pada Harapan Maulina Hijab Jombang). Jurnal EKSIS Vol XNo1, Hal. 13-27

Kotler, Philip dan Kevin Lane Keller.2009.Manajemen

Pemasaran.Edisi 13. Jakarta: Gelora Aksara Pratama

Massie, Philander Varian. 2013. Ekuitas Merek pengaruhnya Terhadap Keputusan Pembelian XL Mobile Data Service di Kota Manado. Jurnal EMBA Vol.1 No.4. Hal. 1474-1481

Meliana, Sulistiono, dan Budi Setiawan. 2013. Pengaruh Kualitas Pelayanan dan Kepercayaan Konsumen Terhadap Keputusan Pembelian (Studi Kasus Pada Giant
Hypermarket). Jurnal Ilmiah Manajemen Kesatuan Vol. 1 No. 3, Hal. 247-254

Mowen, J.C dan Minor, M.2002. Perilaku Konnsumen. Edisi 5. Jakarta: Erlangga

Peter, J.Paul dan Jerry C. Olson.2013.Perilaku Konsumen dan Strategi Pemasaran.Edisi 9. Jakarta: Salemba Empat

Putra, Arfian Bimantara, Edy Yulianto, dan Sunarti. 2014. Pengaruh Bauran Pemasaran Jasa Terhadap Keputusan Pembelian (Survei pada Pelanggan yang Menggunakan Jasa Pengiriman di Kantor Pos Besar Kota Malang). Jurnal Administrasi Bisnis Vol. 1 No. 1. Hal, 1-8

Taroreh, Oktavianus, Rotinsulu Jopie Jorie, dan Rudy Wenas. 2015.Pengaruh Persepsi Konsumen dan Kepercayaan Terhadap Penggunaan Jasa Asuransi Jasindo Manado. Jurnal EMBA. Vol.3 No 3. Hal.312-321

Wibowo. Puji, Nawazirul Lubis, \& Naili Farida. 2013. Analisis Faktor-Faktor Yang Mempengaruhi Keputusan Penggunaan Sistem Listrik Prabayar Sektor Rumah Tangga di Wilayah Semarang Selatan. Diponegoro Journal of Social And Politic. Hal. 1-9

Wulandari, Royani. 2014.Analisis Faktor-faktor yang Mempengaruhi Kepercayaan Konsumen dan Dampaknya Terhadap Minat Loyalitas. Skripsi. Semarang. Universitas Diponegoro. 